\title{
Mean platelet volume levels in children with sleep-disordered breathing: a meta- analysis
}

\author{
Wen-Dien Chang ${ }^{1}$, Chih-Hao Tseng ${ }^{2^{*}+}$ and Yung-An Tsou $3{ }^{3,4^{*}+}$ (D)
}

\begin{abstract}
Background: Pediatric sleep-disordered breathing (SDB) correlated with respiratory conditions of snoring and hypopnea. Mean platelet volume (MPV) was an inflammatory marker, related to increased inflammatory condition of pediatric patients. Increase of MPV level may cause failure to thrive or increased upper airway infection rate. The aim of this study was to perform systematic review and meta-analysis to investigate the difference on MPV values for pediatric SDB, and compare the change on MPV after surgery in patients with pediatric SDB.
\end{abstract}

Methods: A systemic review of the studies from PubMed, EMBASE, and Cochrane Library databases was conducted in March 2020, supported by reviewing of published articles for studies comparing MPV in pediatric SDB. Metaanalysis was used to compare the change of MPV in pediatric SDB, and sub-group analysis was also used to compare the MPV decrease after surgeries of adenoidectomy or adenotonsillectomy.

Results: There were seven studies included in the review. Six of them including 963 subjects showed that a significant increase of MPV was noted in pediatric SDB compared to those in pediatric non-SDB $(P<0.05)$. Total standardized mean difference (SMD) in MPV between pediatric SDB and non-SDB was $0.51(95 \% \mathrm{Cl}=$ $0.30-0.72, P<0.05)$. A significant decrease of MPV was found in pediatric SDB patients who underwent surgery (total $\mathrm{SMD}=-0.36 ; 95 \% \mathrm{Cl}=-0.70--0.02, P<0.05$ ). Decreases of MPV after adenoidectomy and adenotonsillectomy were observed, but only the effect of adenotonsillectomy had a statistical significance (total SMD $=-0.72 ; 95 \% \mathrm{Cl}=-1.18--0.26, P<0.05$ ).

Conclusion: The MPV was significantly higher in patients with pediatric SDB, indicating the presence of increased platelet activity in pediatric SDB patients. The level of MPV could be reduced by the two surgeries, especially adenotonsillectomy.

Keywords: Pediatric sleep disordered breathing, Snoring, Mean platelet volume

\footnotetext{
*Correspondence: joe2013912@gmail.com; d22052121@gmail.com

${ }^{\dagger}$ Yung-An Tsou is a corresponding author, and Chih-Hao Tseng is a cocorresponding author.

${ }^{2}$ Clinical Laboratory, Cheng-Ching General Hospital, Taichung, Taiwan

${ }^{3}$ Department of Otolaryngology-Head and Neck Surgery, China Medical University Hospital, Taichung, Taiwan

Full list of author information is available at the end of the article
}

C C The Author(s). 2020 Open Access This article is licensed under a Creative Commons Attribution 4.0 International License, which permits use, sharing, adaptation, distribution and reproduction in any medium or format, as long as you give appropriate credit to the original author(s) and the source, provide a link to the Creative Commons licence, and indicate if changes were made. The images or other third party material in this article are included in the article's Creative Commons licence, unless indicated otherwise in a credit line to the material. If material is not included in the article's Creative Commons licence and your intended use is not permitted by statutory regulation or exceeds the permitted use, you will need to obtain permission directly from the copyright holder. To view a copy of this licence, visit http://creativecommons.org/licenses/by/4.0/ The Creative Commons Public Domain Dedication waiver (http://creativecommons.org/publicdomain/zero/1.0/) applies to the data made available in this article, unless otherwise stated in a credit line to the data. 


\section{Background}

Pediatric sleep-disordered breathing (SDB) is characterized by loud snoring and or hypopnea at night and is associated with upper airway infections [1], attention disorder [2], and failure to thrive [3]. The pediatric SDB is correlated with pediatric upper respiratory tract infection, failure to thrive, pediatric hypertension [4, 5], and attention deficiency [2]. Pediatric SDB needed to be diagnosis if pediatric patients with night time symptoms of snoring or obstructed breathing during sleep; daytime symptoms such as excessive daytime sleepiness; and associated neuropsychiatric problems as behavioral problems; agitation behavior, poor concentration, and other problems concerning to grow retardation or learning difficulties. Pediatric sleep apnea is defined as AHI > 1 per hour or hypercapnia (PaCO2 $>50 \mathrm{mmHg}$ ) in $25 \%$ sleep time association with snoring, paradoxical thoracoabdominal motion etc. [6]. The association of pediatric SDB caused to increase interest in its role in upper respiratory tract infection [1], and pediatric hypertension $[4,5]$, failure to thrive (increased catabolic status by chronic inflammation) [3], and attention deficiency disorders [2]. Platelet volume correlated with cardiovascular disease [7], and coronary heart disease [8].

Mean platelet volume (MPV) is an inexpensive and simple test, using to measure platelet size, and is a platelet activity marker. MPV was associated with the factors of cardiovascular disease risk, like diabetes [9], hypertension [10], systemic lupus erythematosus [11], and atherosclerosis [12]. MPV is also associated with increase in catabolic metabolic status [13], as well as arterial and venous thrombosis [14]. A recent study have evaluated MPV in adult patients with sleep-disordered breathing [15]. Some studies have shown a significant association between MPV and sleep-disordered breathing in adult patients $[16,17]$. It is reported that adult patients with sleep-disordered breathing have higher MPV, and MPV disease after wearing continuous positive airway pressure [18], and sleep surgery by uvulopalatal flap in adult patients with sleepdisordered breathing [19]. There are very few reports that show the correlation of MVP in patients with pediatric $\mathrm{SDB}$, and relationship of increase of MVP and pediatric SDB was still unclear. This meta-analysis evaluates the relationship of pediatric SDB and MPV by combining data from all the relevant articles. To the best of our knowledge, this is a first meta-analysis on this field of pediatrics. Therefore, the aim of our study was to use systematic review and meta-analysis to investigate the difference on MPV values for pediatric SDB, and compare the change on MPV after surgery in patients with pediatric SDB.

\section{Methods}

\section{Search strategy and data sources}

Articles about the association of pediatric SDB and $\mathrm{MPV}$, were case series, retrospective cohort studies, and randomized clinical trial studies, were searched independently by two researchers. Our searching strategy was based on patient, indicator, control group and outcome (PICO): is there a difference on MPV values for pediatric SDB, and change on MPV after surgery in patients with pediatric SDB? The electronic databases of PubMed, EMBASE, and Cochrane Library were searched primarily based on the combination of the following keywords: "sleep-disordered breathing," "adenotonsillar hypertrophy," "Adenoid hypertrophy," "mean platelet volume," and "platelet" up to March 2020 and published in English. Searched literatures were limited to children from birth to 18 years. The syntaxes were adjusted according to different databases. The reference list of retrieved articles was scanned for all relevant additional articles and reviews by two researchers. The syntaxes for searches in PubMed and EMBASE were as follows:

\section{PubMed}

\#1 ("sleep disordered breathing" [All Fields] OR "sleepdisordered breathing" [All Fields] OR "adenotonsillar hypertrophy" [All Fields] OR "Adenoid hypertrophy" [All Fields]) AND ("infant" [MeSH Terms] OR "child" [MeSH Terms] OR “adolescent” [MeSH Terms]).

\#2 ("mean platelet volume" [All Fields] OR ("blood platelets" [MeSH Terms] OR ("blood" [All Fields] AND "platelets" [All Fields]) OR "blood platelets" [All Fields] OR "platelet" [All Fields])) AND ("infant" [MeSH Terms] OR "child" [MeSH Terms] OR "adolescent" [MeSH Terms]).

$$
\text { \#3 \#1 AND \#2. }
$$

\section{EMBASE}

\#1 'sleep disordered breathing'/exp. OR 'sleep disordered breathing' OR 'sleep-disordered breathing'/exp. OR 'sleep-disordered breathing' OR 'adenotonsillar hypertrophy'/exp. OR 'adenotonsillar hypertrophy' OR 'adenoid hypertrophy'/exp. OR 'adenoid hypertrophy'.

\#2 'mean platelet volume' OR platelet.

\#3 \#1 AND \#2.

\#4 \#3 AND ([adolescent]/lim OR [child]/lim OR [embryo]/lim OR [fetus]/lim OR [infant]/lim OR [newborn]/ lim OR [preschool]/lim OR [school]/lim). 


\section{Study selection}

Two researchers used search criteria to include articles of pediatric patients with sleep disordered breathing (diagnosed either by symptoms or polysomnography), and one of the main outcomes of comparison between patients with and without pediatric SDB was MPV. The second aim is to see whether adenoidectomy and adenotonsillectomy could reduce MPV level before and after surgery. Only articles published in English which survey the pediatric SDB were included. Articles that did not have MPV measure as one of the main outcomes were excluded.

\section{Data extraction and quality assessment}

Data regarding first author, article publication year, country of study, patients population characteristics, and study setting were extracted and collected. Data were extracted by 2 researchers independently using a standardized format. Mean MPV with SD were calculated accordingly.

Subject data in the cases of pediatric SDB and control groups were extracted directly from the data provided in the included articles. As the original publication provided median value of MPV level, one researcher was directly contacted to get more information for metaanalysis. The quality of included articles were assessed using the Methodological Index for Nonrandomized Studies (MINORS) tool by two researchers independently. The MINORS was primarily used to assess the risk of bias and applicability judged as adequately reported, inadequately reported, and not reported, scoring 2, 1, and 0 , respectively [20]. The highest score for noncomparative study was considered 16 , and that for comparative study was considered 24. The scores of MINORS were from 9 to 20, and there was a good consensus regarding study quality.

\section{Statistical analysis}

The comprehensive meta-analysis software (Comprehensive Meta-Analysis Version 3, Biostat Inc., Englewood, NJ) was used to perform for all statistical analyses. Descriptive statistics was used for continuous variable, and the data were presented as mean \pm SD. In meta-analysis, the standardized mean difference (SMD) was used to analyze the MPV level between patients with pediatric SDB and control group as the main measure of association. Fixed or random effects models was used for pooling of the data from the included articles. The estimates of SDM were expressed with 95\% confidence intervals (CIs). The heterogeneity analysis was assessed by Q statistic and $\mathrm{I}^{2}$ statistics, which derived from Cochran $\mathrm{Q}$ statistic. All analysis were two-tailed tests and $P<0.05$ was considered statistically significant. A value of $\mathrm{I}^{2}>50 \%$ was meant substantial magnitude of heterogeneity, and a value of $\mathrm{P}<0.05$ was meant significant heterogeneity. A sensitivity analysis was also performed to determine the impact of the quality score on the findings of this systemic review. The Egger's test and Rosenthal's fail-safe number were used to assess any publication bias [21, 22].

\section{Results}

\section{Data search results}

We used the search strategy to identify 56 articles from the electronic databases, and all articles were screened subsequently by reading titles in Fig. 1 . Nine studies were discarded because of duplication, and 30 were excluded due to lack of appropriateness of title. After remaining the abstracts, 17 articles were read in detail, and another 2 articles were excluded. The excluded records were as following: evaluated platelet activation $(n=1)$, and relationship between MPV and left ventricular function $(\mathrm{n}=1)$. Fifteen articles were selected in full length by 2 reviewers for appropriateness and the criteria. Finally, seven studies were reviewed [23-29].

In Fig. 1, because the study of Onder et al. was noncomparative study without data of control group [25]. Three studies focused on comparison MPV value without surgery $[25,28,29]$, and four studies about MPV level change after surgery involving 744 subjects were included in the meta-analysis [23, 25-27]. Among these included trials, six studies (total subjects, $n=963$ ) compared MPV value between pediatric SDB $(n=552)$ versus non-SDB groups $(n=411)$ [23, 25-29]. Four studies (total subjects, $n=369$ ) compared preoperative versus postoperative values of MPV [23-26].

\section{Study characteristics}

In Table 1, study characteristics of included articles are shown. The endoscopy was used for SDB diagnosis in four studies [23, 25-27], polysomnography was used in three studies [27-29], and cephalometry was used in one study [24]. The MPVs were measured from blood sampling within $1 \mathrm{~h}$, and used EDTA to avoid EDTA-induced platelet swelling. However, the diagnosis of PDSB is only found in three studies according to apnea hypopnea index done by polysomnography [27-29]. There were five studies from Turkey [23-26, 28], one study from Italy [27], and one study from Spain [29]. All the studies published from 2014 to 2019 , and study quality was evaluated using MINORS tool in Table 2.

\section{Outcomes of meta-analysis}

In meta-analysis, six studies on whether the pediatric sleep surgery adenoidectomy and adenotonsillectomy could reduce the MPV level by analysis of the change in 


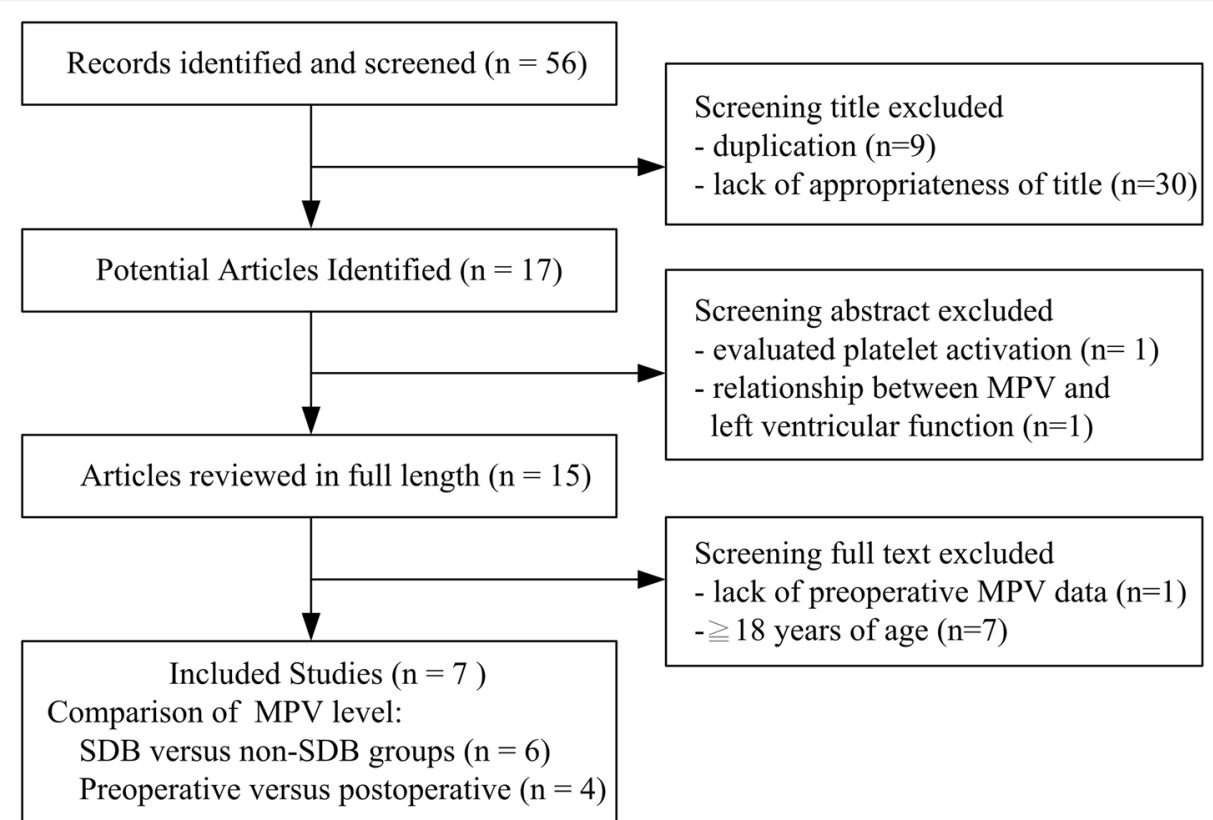

Fig. 1 Study flow diagram: progression of papers through the review process

MPV level of pediatric SDB $(n=552)$ or non-SDB (controls; $n=411$ ) [23, 25-29]. In the study of Erdim et al., two groups receiving adenoidectomy and adenotonsillectomy were meta-analyzed separately to compare control group [28]. In the results of Rosenthal's fail-safe number test, the tolerance level of 35 was lower than the fail-safe number of 75 , resulting publication bias did not affect meta-analysis. No significant publication bias was detected $(t=1.58, P=0.25)$ in Egger's regression intercept analysis. In Fig. 2, comparing patients with pediatric SDB $(n=552)$ to those with non-SDB $(n=449)$ in metaanalysis, a significantly heterogeneous in SMD of MPV values was found $\left(n=1001 ; \quad Q=16.06 ; \quad I^{2}=62.63\right.$; $P<0.05)$. The patients with pediatric SDB had

Table 1 Characteristics of study design, PSDB diagnosis, and included article quality

\begin{tabular}{|c|c|c|c|c|c|}
\hline Authors & Country & Study design & Evaluations & PSDB Diagnosis & MINORS \\
\hline $\begin{array}{l}\text { Kucur } \\
\text { et al. } \\
\text { [23] }\end{array}$ & Turkey & $\begin{array}{l}\text { Prospective study/ } \\
\text { comparative study }\end{array}$ & Endoscopy & $\begin{array}{l}\text { Children had grade } 3 \text { ( } 50 \text { to } 75 \% \text { of choanal space) or } 4 \text { ( } 75 \text { to } 100 \% \text { of } \\
\text { choanal space) adenoid hypertrophy }\end{array}$ & 16 \\
\hline $\begin{array}{l}\text { Onder } \\
\text { et al' } \\
\text { [24] }\end{array}$ & Turkey & $\begin{array}{l}\text { Prospective study/ } \\
\text { noncomparative } \\
\text { study }\end{array}$ & Cephalometry & Children with enlarged adenoid (adenoid/nasopharynx ratio >0.7) & 9 \\
\hline $\begin{array}{l}\text { Soyalic } \\
\text { et al: } \\
{[25]}\end{array}$ & Turkey & $\begin{array}{l}\text { Prospective study/ } \\
\text { comparative study }\end{array}$ & Endoscopy & $\begin{array}{l}\text { Children had grade } 3 \text { (adenoid tissue fill } 50-75 \% \text { of choana) or } 4 \text { (adenoid } \\
\text { tissue fill } 75-100 \% \text { of choana) adenoids, and } 3+(50-75 \% \text { of airway } \\
\text { obstruction) or } 4+\text { (airway obstruction }>75 \%) \text { tonsil hypertrophy }\end{array}$ & 19 \\
\hline $\begin{array}{l}\text { Simsek } \\
\text { et al. } \\
\text { [26] }\end{array}$ & Turkey & $\begin{array}{l}\text { Retrospective study/ } \\
\text { comparative study }\end{array}$ & Endoscopy & $\begin{array}{l}\text { Children with adenoid hypertrophy (choanal space } \geq 50 \% \text { ) or chronic } \\
\text { tonsillitis (repeated attacks } \geq 4 \text { or } 5 \text { per year) }\end{array}$ & 20 \\
\hline $\begin{array}{l}\text { Zicari } \\
\text { et al. } \\
{[27]}\end{array}$ & Italy & $\begin{array}{l}\text { Clinical study/ } \\
\text { comparative study }\end{array}$ & $\begin{array}{l}\text { Endoscopy and } \\
\text { polysomnography }\end{array}$ & $\begin{array}{l}\text { Children had primary snoring (snoring without apnea, abnormal sleep, or } \\
\text { abnormal gas exchange) and obstructive sleep apnea (partial upper airway } \\
\text { obstruction, intermittent complete obstruction during sleep, and loss of } \\
\text { normal ventilation during sleep) }\end{array}$ & 18 \\
\hline $\begin{array}{l}\text { Erdim } \\
\text { et al. } \\
\text { [28] }\end{array}$ & Turkey & $\begin{array}{l}\text { Retrospective study/ } \\
\text { comparative study }\end{array}$ & Polysomnography & Children with predicting sleep apnea (apnea-hypopenea index > 1) & 17 \\
\hline $\begin{array}{l}\text { Barceló } \\
\text { et al. } \\
\text { [29] }\end{array}$ & Spain & $\begin{array}{l}\text { Case-control study/ } \\
\text { comparative study }\end{array}$ & Polysomnography & $\begin{array}{l}\text { Children with snoring and obstructive sleep apnea (apnea-hypopenea index } \\
>1 \text {, decrease of hypopnea } \geq 30 \% \text { ) }\end{array}$ & 17 \\
\hline
\end{tabular}


Table 2 Characteristics of subject number, MPV and study reports

\begin{tabular}{|c|c|c|c|c|c|c|c|c|}
\hline Authors & $\begin{array}{l}\text { Total } \\
\text { subjects } \\
\text { (n) }\end{array}$ & $\begin{array}{l}\text { PSDB } \\
(n)\end{array}$ & $\begin{array}{l}\text { Controls } \\
\text { (n) }\end{array}$ & $\begin{array}{l}\text { MPV in } \\
\text { PSDB }\end{array}$ & $\begin{array}{l}\text { MPV in } \\
\text { controls }\end{array}$ & $\begin{array}{l}\text { Subjects with } \\
\text { surgery (n) }\end{array}$ & $\begin{array}{l}\text { MPV in } \\
\text { post- } \\
\text { surgery }\end{array}$ & Study reports \\
\hline $\begin{array}{l}\text { Kucur } \\
\text { et al. [23] }\end{array}$ & 205 & 105 & 100 & $\begin{array}{l}8.25 \pm \\
1.10\end{array}$ & $\begin{array}{l}7.50 \pm \\
0.90\end{array}$ & 105 & $7.75 \pm 1.20$ & Significant decrease in adenoid hypertrophy * \\
\hline $\begin{array}{l}\text { Onder } \\
\text { et al' [24] }\end{array}$ & 61 & 61 & NA & $\begin{array}{l}7.5 \pm \\
1.07\end{array}$ & NA & 61 & $7.70 \pm 0.80$ & $\begin{array}{l}\text { Significant decreases in white blood cell levels and } \\
\text { upper airway obstruction scores* }\end{array}$ \\
\hline $\begin{array}{l}\text { Soyalic } \\
\text { et al' [25] }\end{array}$ & 129 & 73 & 56 & $\begin{array}{l}7.68 \pm \\
1.07\end{array}$ & $\begin{array}{l}7.21 \pm \\
0.84\end{array}$ & 73 & $7.17 \pm 0.97$ & Significant decreases in MPV level and platelet count* \\
\hline $\begin{array}{l}\text { Simsek } \\
\text { et al. [26] }\end{array}$ & 212 & 130 & 82 & $\begin{array}{l}8.24 \pm \\
0.94\end{array}$ & $\begin{array}{l}7.76 \pm \\
0.77\end{array}$ & 130 & $7.82 \pm 0.93$ & $\begin{array}{l}\text { Significant decreases in MPV, platelet distribution } \\
\text { width, hemoglobin, and white blood cell, }{ }^{*}, a\end{array}$ \\
\hline $\begin{array}{l}\text { Zicari } \\
\text { et al. [27] }\end{array}$ & 137 & 67 & 70 & $\begin{array}{l}8.22 \pm \\
0.95\end{array}$ & $\begin{array}{l}7.57 \pm \\
0.56\end{array}$ & NA & NA & MPV levels were higher in PSDB \\
\hline $\begin{array}{l}\text { Erdim } \\
\text { et al. [28] }\end{array}$ & 83 & 45 & 38 & $\begin{array}{l}7.93 \pm \\
0.59^{\mathrm{b}} \\
8.05 \pm \\
0.68^{\mathrm{c}}\end{array}$ & $\begin{array}{l}7.72 \pm \\
0.38\end{array}$ & NA & NA & MPV levels were higher in PSDB \\
\hline $\begin{array}{l}\text { Barceló } \\
\text { et al. [29] }\end{array}$ & 152 & 87 & 65 & $\begin{array}{l}7.40 \pm \\
0.97\end{array}$ & $\begin{array}{l}7.40 \pm \\
0.95\end{array}$ & NA & NA & No differences in MPV \\
\hline
\end{tabular}

MPV expressed as mean \pm SD in $\mathrm{fL} ;$ MPV mean platelet volume, PSDB pediatric sleep breathing disorder, NA not available

${ }^{*} P<0.05$, pre- vs. post-operation in PSDB patients; ${ }^{\text {a }}$ Significant decreases after adenotonsillectomy were found, but no significant decreases after adenoidectomy were noted; ${ }^{b} 1 \leq$ apnea-hypopenea index $<5(n=24)$; ${ }^{c}$ apnea-hypopenea index $\geq 5(n=21)$

significant higher MPV value than healthy control group (total SMD $=0.51 ; 95 \% \mathrm{CI}=0.30-0.72, P<0.05$ ).

Compared to pediatric non-SDB group, the MPV values, white blood cell levels, upper airway obstruction and adenoid hypertrophy were significantly reduced after surgery in patients with pediatric SDB among these including studies [23-26]. Of all articles, three studies were used adenoidectomy [23, 24, 26], and two studies used adenotonsillectomy for pediatric SDB [25, 26]. The MPV values were compared between pre- and postsurgery in meta-analysis (Fig. 3). Among the patients with pediatric SDB, there was significant heterogeneity in SMD of MPV value pre- and post-surgery $(n=369$; $\left.\mathrm{Q}=65.31 ; \mathrm{I}^{2}=93.87 ; P<0.05\right)$. A significant decrease of MPV found in pediatric SDB patients who underwent surgery (total SMD $=-0.36 ; 95 \% \mathrm{CI}=-0.70--0.02, P<$ $0.05)$. The results of forest plot for meta-analysis showed a significant decrease of MPV in post-surgery group.

In sub-group analysis, MPV values were compared before and after adenoidectomy or adenotonsillectomy. The patients received the adenoidectomy in three studies $[23,24,26]$, and received the adenotonsillectomy in two

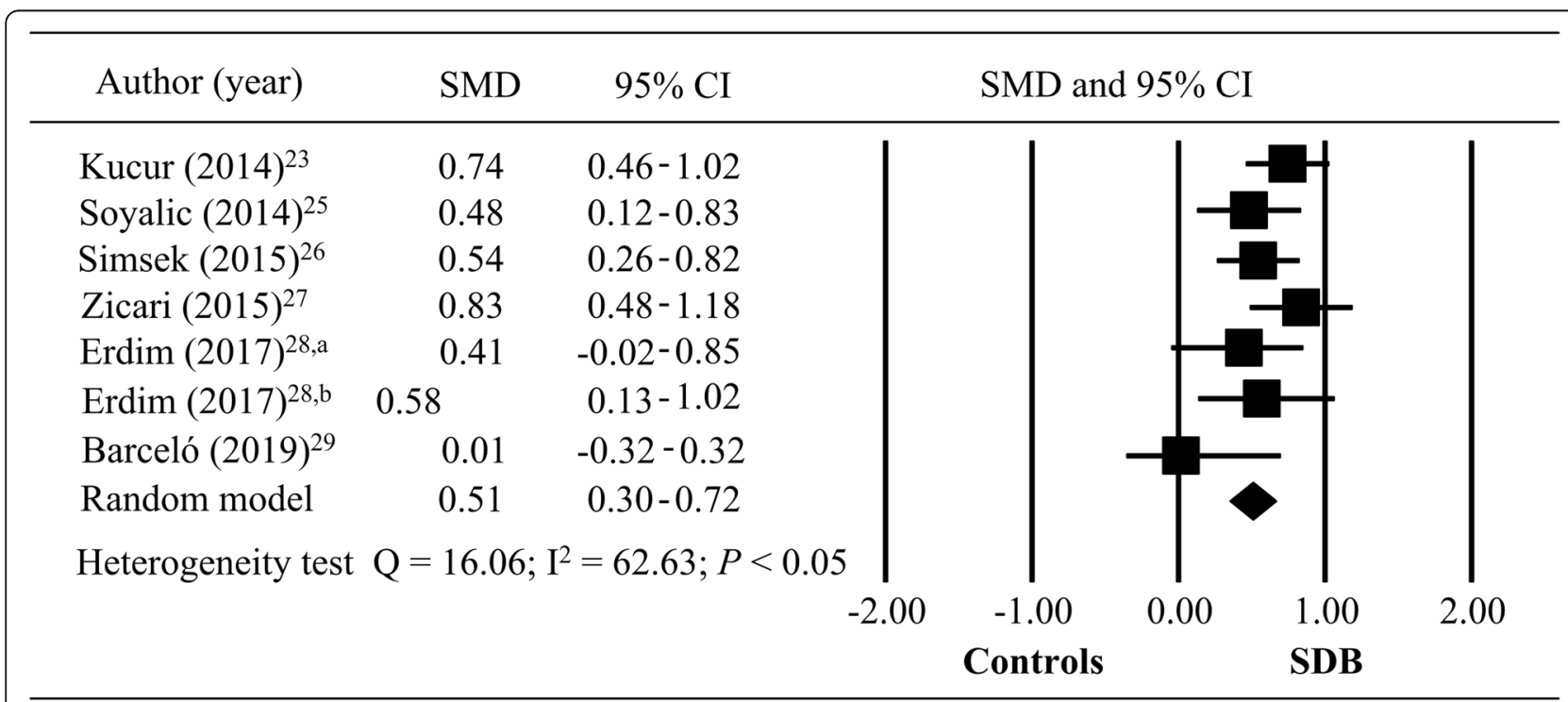

Fig. 2 Meta-analysis of pediatric SDB and control groups (SDB, sleep-disordered breathing; SMD: standardized mean difference; Cl: confidence interval) 


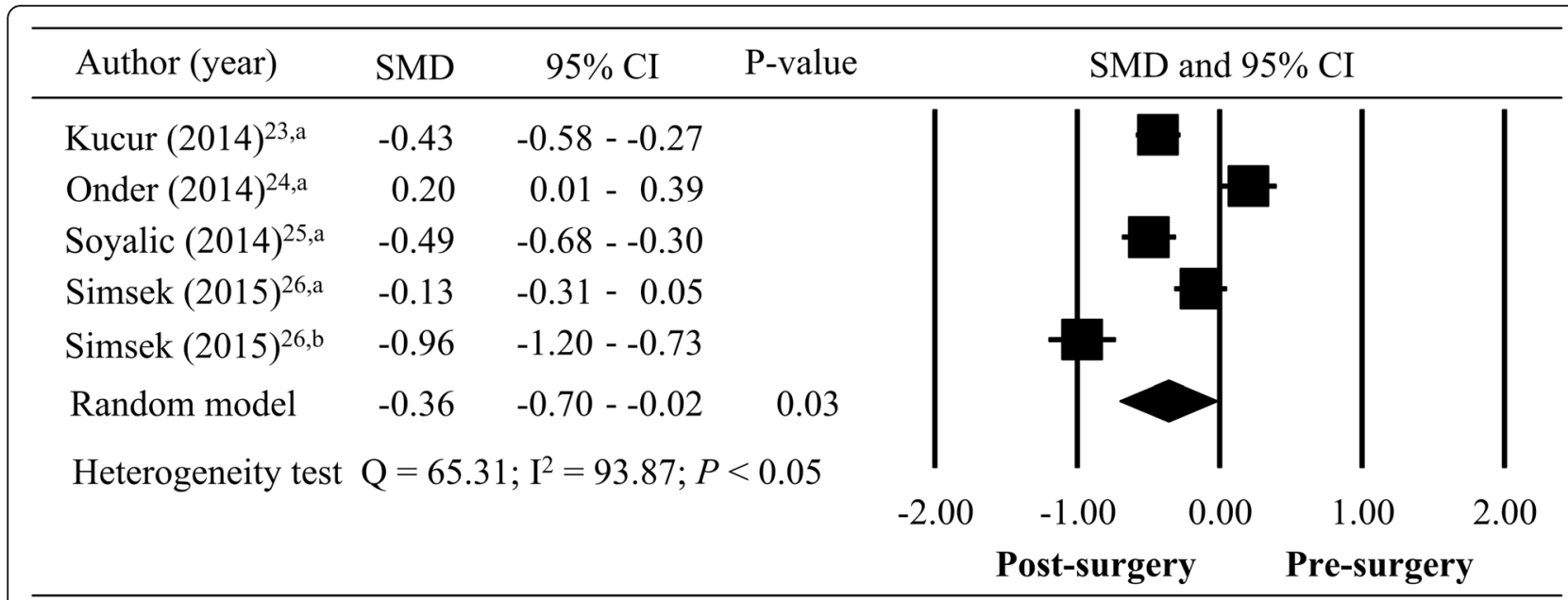

Fig. 3 Meta-analysis of pre- and post-surgery (adenoidectomy ${ }^{\mathrm{a}}$ and adenotonsillectomy ${ }^{\mathrm{b}}$; SMD: standardized mean difference; $\mathrm{Cl}_{\text {: }}$ confidence interval)

studies [25, 26]. In Fig. 4, there were significant heterogeneous in SMD of MPV for the patients who underwent adenoidectomy $\left(n=235 ; \quad \mathrm{Q}=24.93 ; \quad \mathrm{I}^{2}=91.99\right.$; $P<0.05)$ and adenotonsillectomy $\left(n=134 ; \mathrm{Q}=9.30 ; \mathrm{I}^{2}=\right.$ 89.25; $P<0.05)$. Decrease of MPV after adenoidectomy was observed, but statistical significance was not reached (total $\mathrm{SMD}=-0.12 ; 95 \% \mathrm{CI}=-0.48-0.23, P>0.05$ ). However, a significant decrease of MPV were reported in the patients who underwent surgery of adenotonsillectomy (total SMD $=-0.72 ; 95 \% \mathrm{CI}=-1.18--0.26$, $P<0.05$, Fig. 4).

\section{Discussion}

As far as we know, our study is the first systematic review and meta-analysis to the difference on MPV between SDB and healthy children, and compare the change on MPV after adenoidectomy and adenotonsillectomy in patients with pediatric SDB. Our analysis drawn from seven reviewed articles and involved 963 participants (pediatric SDB, $n=552$; controls, $n=411$ ) for meta-analysis. Compared with control group, the MPV level is significantly higher in patients with pediatric SDB in the results of metaanalysis $(P<0.05)$. The subgrouping analysis (pediatric SDB patients underwent surgery, $n=369$ ), also show the adenoidectomy and adenotonsillectomy could reduce the MPV level.

MPV level is a measure of routine complete blood count, and platelets could help prevent bleeding. Of our reviewed articles, MPV level was measured as one blood parameter for pediatric SDB [23-29]. Six of them surveyed the MPV level versus control for pediatric SDB, and 4 of them surveyed the MPV level change between surgery and non-surgery groups

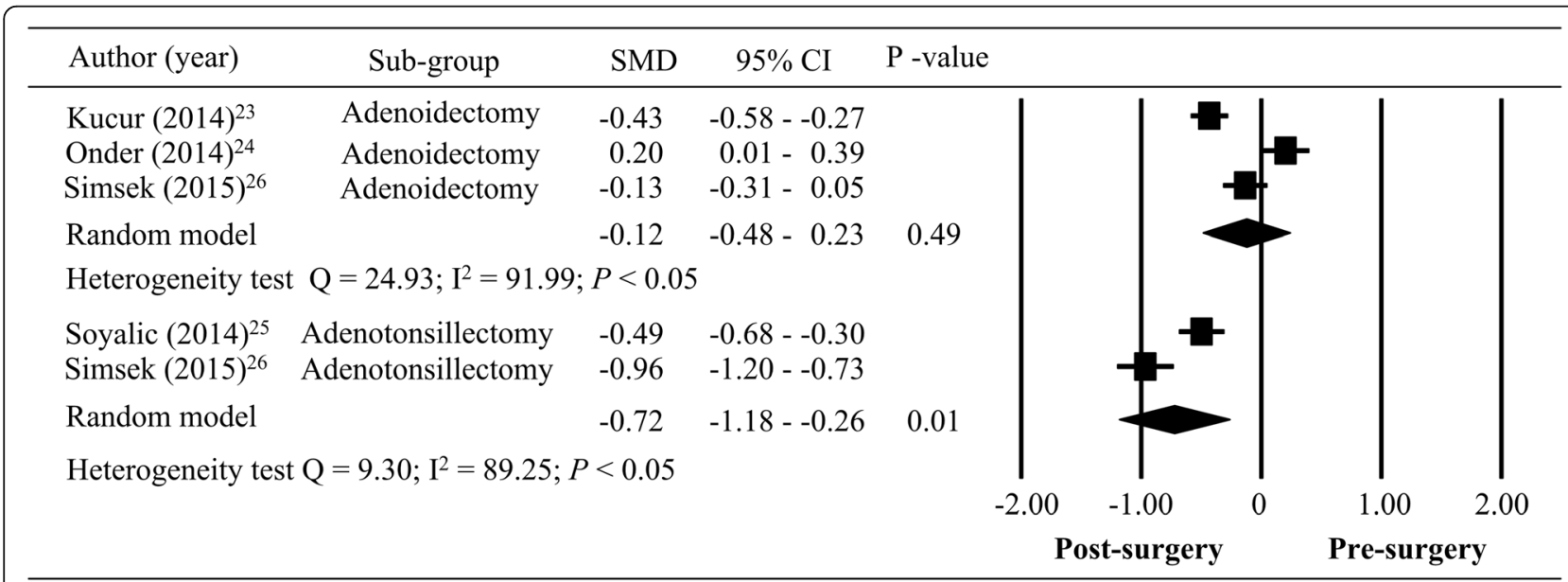

Fig. 4 Sub-group analysis for adenoidectomy and adenotonsillectomy, pre- and post-surgery (SMD: standardized mean difference; Cl: confidence interval) 
which make this meta-analysis all the more important [23, 25-29]. Pediatric SDB attracts the sleep physicians', pediatricians', and otolaryngologists' concerns much more because of its increasing prevalence rate and its sequelae if left alone which include pediatric hypertension [30], increased risk of upper respiratory tract infection [31], failure to thrive [32], and neuropsychiatric problems such as attention deficiency [33], and other mood disorders such as depression [34, 35]. Previous studies have indicated an increase in pediatric hypertension rates in patients with pediatric SDB even in non-obese pediatric groups $[4,30]$. There were proatherogenic molecules, including tumor necrosis factor-a (TNF- $\alpha$ ), interleukin-6 (IL-6), oxidized low density lipoprotein cholesterol, correlates to increased resistance to insulin and to active macrophage. They affected platelet volume to accelerate atherosclerosis and increase cardiovascular disease in patients with pediatric SDB and related sleep breathing disorders [36]. The pathophysiological mechanism for increased platelet volume observed in pediatric SDB is not yet clearly defined, and several explanations have been discussed in our results of metaanalysis [23, 25-29]. Pediatric SDB is related to chronic inflammatory condition such as chronic tonsillitis and chronic adenoiditis, with raised in various inflammatory mediators, such as TNF- $\alpha$, IL- 1 and IL6 [36]. Platelets have been reported to activate these inflammatory cytokines and chemokines by changing in size, measured as MPV [36].

Increased MPV is also associated with poor outcomes after a stroke and a higher risk of coronary stent restenosis rate, which is related to vessels' endothelial dysfunction. We did not see these associations in patients with pediatric SDB; however, we did find the association of pediatric vessels endothelial dysfunction in SDB children, which might lead to cardiovascular diseases $[37,38]$. There are possible inflammatory cytokines such as renin, angiotensin, VEGF, insulin growth factor, TNF-alpha triggered by increased platelet volume rendered change blood pressure in patients with pediatric SDB. A related study also showed a positive correlation between activated platelet function to elevated MPV [38].

In our meta-analysis, MPV level is significantly higher in pediatric SDB patients compared to control group, revealing the presence of increased platelet activity in pediatric SDB patients. However, MPV level was measured as a clinical blood marker for elevated blood pressure, and it is needed to establish the pediatric hypertension in patients with pediatric SDB. There were insufficient information to infer conclusion on increased MPV in patients with pediatric SDB was responsible for higher blood pressure events in meta-analysis from six articles [23, 25-29]. Further studies are required to answer and discuss this. We also found the adenotonsillectomy significant reduced MPV when compared to adenoidectomy alone for patients with pediatric SDB. We presumed that this might due to more patency of upper airway and decreasing the hypoxic condition that leads to deactivation of platelet function. The other possible explanation is that eradicating inflammatory tissues (adenoid plus palatine tonsils) and the resulting decrease in residual inflammatory tissue ceases the active activation of platelet function and leads to decreased MPV.

In our review, we found chronic tonsillitis and adenoiditis in pediatric patients is highly correlated to pediatric sleep disordered breathing. The children with SDB were often to have adenoid or tonsillar hypertrophy, which could be diagnosed endoscopically, and most of them suffered from snoring, obstructive sleep apnea, or a chronic inflammatory condition such as chronic tonsillitis or chronic adenoiditis. Surgical adenoidectomy or adenotonsillectomy could decrease tissue vibration trauma, decrease hypoxia, and even eradicate hidden infection sources such as biofilm. These could subsequently decrease tissue vibration damage, help patients recover endothelial function and even decrease bacterial tissue reactions. All of these factors contribute to decrease the level of MPV (Fig. 5). This will help reduce the pediatric inflammatory condition and improve oxygenation during night time sleeping and decrease the subsequent upper airway infections.

\section{Limitations}

In our review, we found that there is a broadspectrum MPV level, ranging $6.0 \sim 9.36 \mathrm{fL}$. An essential limitation was the effect of severity of pediatric SDB on the value of MPV in patients with pediatric SDB, as not all of the included studies proved pediatric SDB by polysomnography or sleep questionnaire. In addition, most of papers identified for meta-analysis were from Turkey and one from Italy and two were the same group authors, this might cause selection bias but there were few studies focus on MPV relating to the treatment outcomes and severity of pediatric SDB, therefore we could only use these studies for meta-analysis. By the way, we also did a subgroup analysis on whether surgery affected the MPV level when compared with no surgery. Although the MPV was still higher in patients who underwent pediatric SDB surgery, the MPV level decreased significantly after surgery. The effects of inflammatory markers on MPV were also not analyzed 


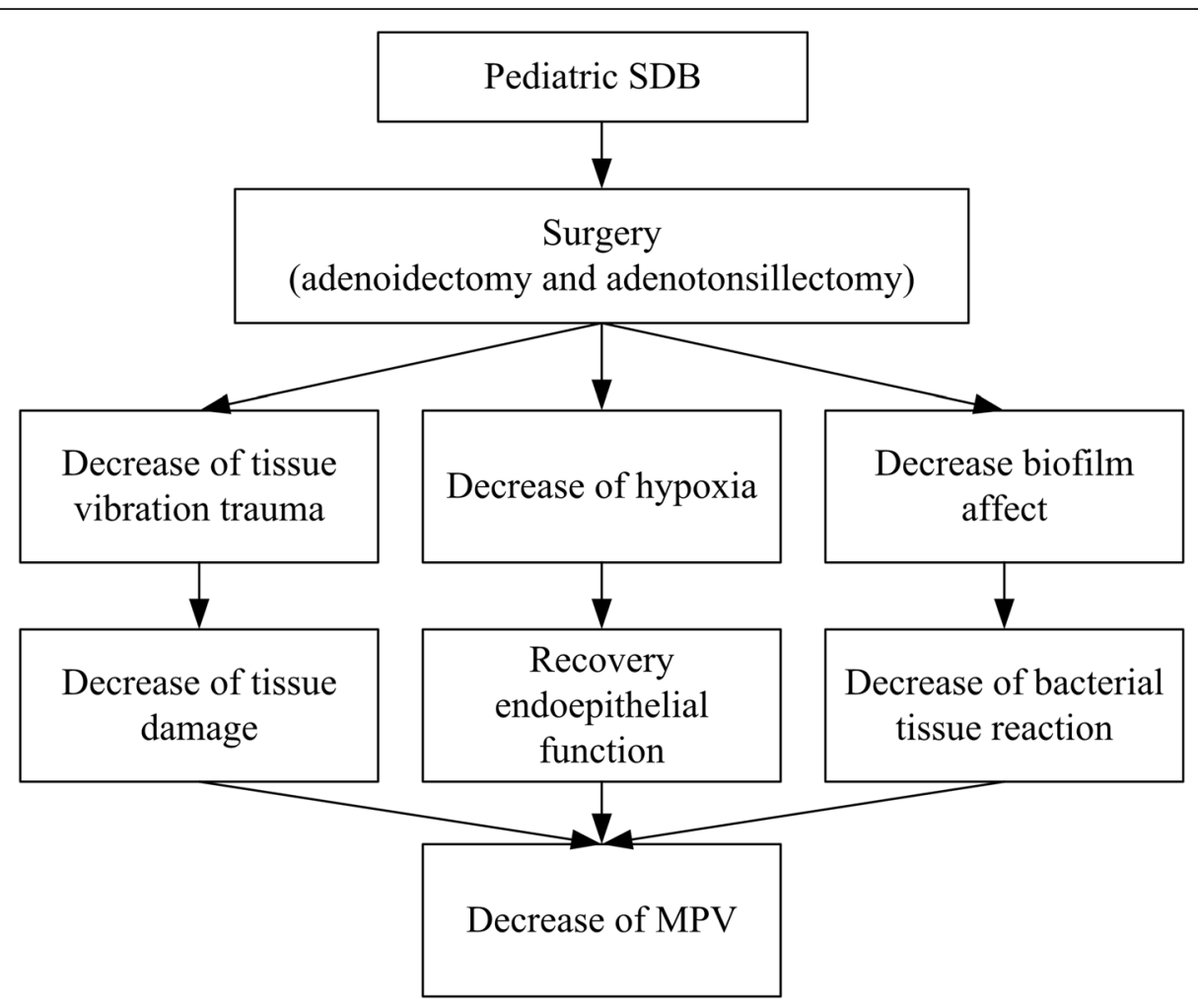

Fig. 5 The proposed reasons of adenoidectomy and adenotonsillectomy influencing MPV

in out study. Another limitation in this review is that measured MPV values were so various from different laboratories that SMD was used for standardizing in our meta-analysis.

\section{Conclusions}

This study suggests that the MPV was significantly higher in patients with pediatric SDB, indicating the presence of increased platelet activity in pediatric SDB patients. The level of MPV could be reduced by the two surgeries, especially adenotonsillectomy. The increased MPV is associated with increased blood pressure and inflammatory markers in pediatric SDB patients were needed to be studied in the future.

\section{Abbreviations}

PICO: Patient, indicator, control group and outcome; SDB: Sleep-disordered breathing; MINORS: Methodological Index for Nonrandomized Studies; MPV: Mean platelet volume; SMD: Standardized mean difference;

Cl: Confidence interval; IL-6: Interleukin-6; TNF- $a$ : Tumor necrosis factor- $a$

\section{Acknowledgements}

The authors would like to thank Jean-Luc Baker of Lamar University to help the English editing in our manuscript.

\section{Authors' contributions}

WC made significant contributions to the acquisition of data, and critical revision of the manuscript. $\mathrm{CH}$ made significant contributions to the analysis and interpretation of data, and statistical analysis. YT made significant contributions to the conception and design, acquisition of data, analysis and interpretation of data, drafting and critical revision of the manuscript. All authors have read and approved the manuscript.

\section{Funding}

None.

Availability of data and materials

All data generated or analyzed during this study are included in this published article.

Ethics approval and consent to participate

Not Applicable.

Consent for publication

Not Applicable.

Competing interests

The authors declare that they do not have any competing interests.

\section{Author details}

${ }^{1}$ Department of Sport Performance, National Taiwan University of Sport, Taichung, Taiwan. ${ }^{2}$ Clinical Laboratory, Cheng-Ching General Hospital, Taichung, Taiwan. ${ }^{3}$ Department of Otolaryngology-Head and Neck Surgery, China Medical University Hospital, Taichung, Taiwan. ${ }^{4}$ Department of Audiology and Speech-Language Pathology, Asia University, No. 91, Hsueh-Shih Road, Taichung, Taiwan.

Received: 12 September 2019 Accepted: 22 April 2020

Published online: 11 May 2020

\section{References}

1. Johnston J, McLaren H, Mahadevan M, Douglas RG. Clinical characteristics of obstructive sleep apnea versus infectious adenotonsillar hyperplasia in children. Int J Pediatr Otorhinolaryngol. 2019;116:177-80. 
2. Sedky K, Bennett DS, Carvalho KS. Attention deficit hyperactivity disorder and sleep disordered breathing in pediatric populations: a meta-analysis. Sleep Med Rev. 2014;18:349-56

3. Esteller E, Villatoro JC, Agüero A, Lopez R, Matiñó E, Argemi J, GirabentFarrés M. Obstructive sleep apnea syndrome and growth failure. Int J Pediatr Otorhinolaryngol. 2018;108:214-8.

4. Lee CH, Kang KT, Chiu SN, Chang IS, Weng WC, Lee PL, Hsu WC. Association of adenotonsillectomy with blood pressure among hypertensive and nonhypertensive children with obstructive sleep apnea. JAMA Otolaryngol Head Neck Surg. 2018;144:300-7.

5. Lee LA, Li HY, Lin YS, Fang TJ, Huang YS, Hsu JF, Wu CM, Huang CG. Severity of childhood obstructive sleep apnea and hypertension improved after adenotonsillectomy. Otolaryngol Head Neck Surg. 2015;152:553-60.

6. Li Z, Celestin J, Lockey RF. Pediatric sleep apnea syndrome: an update. J Allergy Clin Immunol Pract. 2016;4:852-61.

7. Papapanagiotou A, Daskalakis G, Siasos G, Gargalionis A, Papavassiliou AG. The role of platelets in cardiovascular disease: molecular mechanisms. Cur Pharm Des. 2016;22:4493-505.

8. Ibrahim H, Kleiman NS. Platelet pathophysiology, pharmacology, and function in coronary artery disease. Coron Artery Dis. 2017;28:614-23.

9. Hudzik B, Korzonek-Szlacheta I, Szkodziński J, Liszka R, Lekston A, Zubelewicz-Szkodzińska B, Gąsior M. Association between multimorbidity and mean platelet volume in diabetic patients with acute myocardial infarction. Acta Diabetol. 2018;55:175-83.

10. Uçar H, Gür M, Gözükara MY, Kıvrak A, Kolcu Z, Akyol S, Kaypaklı O, Elbasan Z, Şahin DY, Türkoğlu C, Şeker T, Çaylı M. Relationship between mean platelet volume and morning blood pressure surge in newly diagnosed hypertensive patients. Anatol J Cardiol. 2015;15:107-12.

11. Hartmann LT, Alegretti AP, Machado ABMP, Martins EF, da Silva Chakr RM, Gasparin AA, Monticielo OA. Assessment of mean platelet volume in patients with systemic lupus erythematosus. Open Rheumatol J. 2018;12: 129-38

12. Berger JS, Eraso LH, Xie D, Sha D, Mohler ER. Mean platelet volume and prevalence of peripheral artery disease, the National Health and nutrition examination survey, 1999-2004. Atherosclerosis. 2010;213:586-91.

13. Zhao F, Yan Z, Meng Z, Li X, Liu M, Ren X, Zhu M, He Q, Zhang Q, Song K, Jia Q, Zhang C, Wang H, Liu X, Zhang X, Wang X, Pan Z, Liu X, Zhang W. Relationship between mean platelet volume and metabolic syndrome in Chinese patients. Sci Rep. 2018;8:14574.

14. Panova-Noeva M, Arnold N, Hermanns MI, Prochaska JH, Schulz A, Spronk HM, Binder H, Pfeiffer N, Beutel M, Blankenberg S, Zeller T, Lotz J, Münzel T, Lackner KJ, Ten Cate H, Wild PS. Mean platelet volume and arterial stiffnessclinical relationship and common genetic variability. Sci Rep. 2017;7:40229.

15. Archontogeorgis K, Voulgaris A, Papanas N, Nena E, Froudarakis M Mikhailidis DP, Steiropoulos P. Mean platelet volume and platelet distribution width in patients with obstructive sleep apnea syndrome and concurrent chronic obstructive pulmonary disease. Clin Appl Thromb Hemost. 2018;24:1216-22.

16. Sarioglu N, Demirpolat G, Erel F, Kose M. Which is the ideal marker for early atherosclerosis in obstructive sleep apnea- carotid intima-media thickness or mean platelet volume? Med Sci Monit. 2017;23:1674-81.

17. Esen E, Özdoğan F, Özel HE, Yılmaz Z, Yüce T, Başer S, Genç S, Selçuk A. Mean platelet volume play a role in disease severity in patients with obstructive sleep apnea syndrome? Kulak Burun Bogaz Ihtis Derg. 2015;25:343-5.

18. Feliciano A, Linhas R, Marçôa R, Cysneiros A, Martinho C, Reis RP, Penque D, Pinto P, Bárbara C. Hematological evaluation in males with obstructive sleep apnea before and after positive airway pressure. Rev Port Pneumol. 2017;23: 71-8.

19. Simsek G, Haytoglu S, Muluk NB, Arikan OK, Cortuk M, Kiraz K. Mean platelet volume decreases in adult patients with obstructive sleep apnea after uvulopalatal flap surgery. J Craniofac Surg. 2015;26:2152-4.

20. Slim K, Nini E, Forestier D, Kwiatkowski F, Panis Y, Chipponi J. Methodological index for non-randomized studies (minors): development and validation of a new instrument. ANZ J Surg. 2003;73:712-6.

21. Egger M, Smith GD, Schneider M, Minder C. Bias in meta-analysis detected by a simple, graphical test. BMJ. 1997;315:629-34.

22. Rosenthal R. The file drawer problem and tolerance for null results. Psychol Bull. 1979;86:638-41.

23. Kucur C, Kulekci S, Zorlu A, Savran B, Oghan F, Yildirim N. Mean platelet volume levels in children with adenoid hypertrophy. J Craniofac Surg. 2014; 25:29-31.
24. Onder S, Caypinar B, Sahin-Yilmaz A, Toros SZ, Oysu C. Relation of mean platelet volume with obstructive adenoid hypertrophy in children. Int J Pediatr Otorhinolaryngol. 2014;78:1449-51.

25. Soyalıç H, Somuk BT, Doğru S, Gürbüzler L, Göktaş G, Eyibilen A. Evaluation of mean platelet volume and its ratio over platelet count in children with obstructive sleep apnea syndrome. Kulak Burun Bogaz Ihtis Derg. 2015;25: $16-21$.

26. Simsek G, Karacayli C, Ozel A, Arslan B, Muluk NB, Kilic R. Blood parameters as indicators of upper airway obstruction in children with adenoid or adenotonsillar hypertrophy. J Craniofac Surg. 2015;26:213-6.

27. Zicari AM, Occasi F, Di Mauro F, Lollobrigida V, Di Fraia M, Savastano V, Loffredo L, Nicita F, Spalice A, Duse M. Mean platelet volume, vitamin D and $C$ reactive protein levels in normal weight children with primary snoring and obstructive sleep apnea syndrome. PLoS One. 2016;11:0152497.

28. Erdim I, Erdur O, Oghan F, Mete F, Celik M. Blood count values and ratios for predicting sleep apnea in obese children. Int J Pediatr Otorhinolaryngol. 2017;98:85-90.

29. Barceló A, Morell-Garcia D, Sanchís P, Peña-Zarza JA, Bauça JM, Piérola J, de la Peña M, Toledo-Pons N, Giménez $P$, Ribot C, Alonso-Fernández A. Prothrombotic state in children with obstructive sleep apnea. Sleep Med. 2019;53:101-5.

30. Horne RS, Wijayaratne P, Nixon GM, Walter LM. Sleep and sleep disordered breathing in children with Down syndrome: effects on behaviour, neurocognition and the cardiovascular system. Sleep Med Rev. 2019:44:1-11.

31. Shen L, Lin Z, Lin X, Yang Z. Risk factors associated with obstructive sleep apnea-hypopnea syndrome in Chinese children: a single center retrospective case-control study. PLoS One. 2018;13:0203695.

32. Stone RS, Spiegel JH. Prevalence of obstructive sleep disturbance in children with failure to thrive. J Otolaryngol Head Neck Surg. 2009;38:573-9.

33. Hill CM, Hogan AM, Onugha N, Harrison D, Cooper S, McGrigor VJ, Datta A, Kirkham FJ. Increased cerebral blood flow velocity in children with mild sleep-disordered breathing: a possible association with abnormal neuropsychological function. Pediatrics. 2006;118:1100-8.

34. Chang CH, Chen SJ, Liu CY. Pediatric sleep apnea and depressive disorders risk: a population-based 15-year retrospective cohort study. PLoS One. 2017; 12:0181430

35. Kim DY, Ko KO, Lim JW, Yoon JM, Song YH, Cheon EJ. The improvement of right ventricular function after adenotonsillectomy in children with obstructive sleep apnea. Korean J Pediatr. 2018;61:392-6.

36. Tan HL, Gozal D, Kheirandish-Gozal L. Obstructive sleep apnea in children: a critical update. Nat Sci Sleep. 2013;5:109-23.

37. Kheirandish-Gozal L. The endothelium as a target in pediatric OSA. Front Neurol. 2012;3:92.

38. Zou S, Teixeira AM, Kostadima M, Astle WJ, Radhakrishnan A, Simon LM, Truman L, Fang JS, Hwa J, Zhang PX, van der Harst P, Bray PF, Ouwehand WH, Frontini M, Krause DS. SNP in human ARHGEF3 promoter is associated with DNase hypersensitivity, transcript level and platelet function, and Arhgef3 KO mice have increased mean platelet volume. PLoS One. 2017;12: 0178095.

\section{Publisher's Note}

Springer Nature remains neutral with regard to jurisdictional claims in published maps and institutional affiliations.

Ready to submit your research? Choose BMC and benefit from:

- fast, convenient online submission

- thorough peer review by experienced researchers in your field

- rapid publication on acceptance

- support for research data, including large and complex data types

- gold Open Access which fosters wider collaboration and increased citations

- maximum visibility for your research: over $100 \mathrm{M}$ website views per year

At $\mathrm{BMC}$, research is always in progress.

Learn more biomedcentral.com/submissions 